\title{
A Rankean Moment in Japan: The Persona of the Historian and the Globalization of the Discipline, $c .1900$
}

\author{
Michael Facius* \\ Tokyo College, The University of Tokyo \\ *Corresponding author. E-mail: michael.facius@mail.u-tokyo.ac.jp
}

This article attends to a formative moment in the history of Japanese historiography around 1900, when many Japanese historians began to identify with the eminent German historian Leopold von Ranke-curiously, however, without a substantial preceding engagement with his work. The article employs the concept of the "scholarly persona" to explore the views of influential Japanese historians on the significance of Leopold von Ranke as an embodiment of scholarly virtues. Contrasting Ranke's image in Japan with that prevalent among German and European practitioners, the article argues that Ranke did not function as a marker of a "Western" or "modern" way of doing history, as most previous accounts of his impact in Japan have asserted, but as a universally appropriable icon of a globalizing discipline.

The Prussian historian Leopold von Ranke (1795-1886) enjoys the elevated status of a founding father of the historical discipline. Already during his lifetime, this image spread beyond German borders. Historians in Great Britain and the United States, but also Hungary, China and Japan, began to imagine themselves as working in a Rankean tradition. ${ }^{1}$ However, chroniclers of Ranke's legacy soon noticed a growing gap between, on the one hand, the exaltation of the figure of Ranke and a small number of tenets associated with his method, and, on the other, the actual intellectual impact of his works. Already in in 1913, the German historian Friedrich Meinecke commented that Ranke had become "something entirely new, a great phenomenon

\footnotetext{
${ }^{1}$ On Ranke see the two recent biographies by Andreas D. Boldt, Leopold von Ranke: A Biography (Milton Park, 2019); and Dominic Juhnke, Leopold Ranke: Biografie eines Geschichtsbesessenen (Berlin, 2015); as well as Günter Johannes Henz, Leopold von Ranke in Geschichtsdenken und Forschung, vol. 2, Grundlagen und Wege der Forschung (Berlin, 2014). On Ranke in America see Georg G. Iggers, "The Image of Ranke in American and German Historical Thought," History and Theory 2/1 (1962), 17-40; in Great Britain: Doris S. Goldstein, "History at Oxford and Cambridge: Professionalization and the Influence of Ranke," in Georg G. Iggers and James M. Powell, eds., Leopold von Ranke and the Shaping of the Historical Discipline (Syracuse, 1990), 141-53; in Hungary: Attila Pók, "Rankes Einfluß auf Geschichtsschreibung und Geschichtsdenken in Ungarn: Ein historisierter Historiker," in Wolfgang J. Mommsen, ed., Leopold von Ranke und die moderne Geschichtswissenschaft (Stuttgart, 1988), 201-14; in China: Xiaoqian Li, "Lanke shixue zai wanqing de chuanbo," Anhui shixue, March 2009, 22-9.

(C) The Author(s), 2020. Published by Cambridge University Press. This is an Open Access article, distributed under the terms of the Creative Commons Attribution licence (http://creativecommons.org/licenses/by/4.0/), which permits unrestricted re-use, distribution, and reproduction in any medium, provided the original work is properly cited.
} 
in the history of ideas." ${ }^{2}$ The influential historian of historiography Georg Iggers later claimed in a similar vein that "what Ranke had thought, was, in a sense, less important to the development of historiography than was the image of Ranke in the historian's mind," and concluded that he "possessed less influence as a great historian than as embodiment of a norm to be accepted or rejected."

Taking Iggers's assessment as a point of departure, this article reconsiders Ranke's role in the development of historical scholarship in late nineteenth-century Japan. While the literature in English and German so far has upheld the claim of a substantial intellectual impact of Rankean historiography on Japanese historians, this article will show that there is indeed very little evidence for this, but that the short outburst of interest in Ranke around 1900, which will be called a "Rankean moment" here, is instead best read as emerging from a concern with norms and virtues of scholarly practice that had little to do with Ranke per se.

In recent years, historians of knowledge such as Lorraine Daston, Otto Sibum and Herman Paul have developed the concept of the scholarly persona in order to elaborate the notion of scientists and scholars such as Ranke acting as an embodiment of norms. They understand personae as abstract models of good scholarship that mediate between the level of the individual scholar and institutions of knowledge production. In their view, personae bundle traits, skills and virtues into repertoires and identities that a scholar must learn, embody and perform to be accepted as a legitimate member of a scholarly community. ${ }^{4}$ Personae are never singular or uncontested but compete for attention and relevance in a given institution, discipline or national academic culture. They need not necessarily be personalized or even labeled, as they permeate both the discourses and practices of a given community: a historian might laud the diligence of a colleague in an obituary, make a remark at a conference about a research approach being too political, or demand more rigor when reviewing a journal article. But there are also times when models will be debated more systematically, especially in periods of intense institutional and intellectual change. They might be condensed into archetypes like the Naturforscher, the philologist or, in recent times, the academic manager. Sometimes, individual scholars whose scholarly conduct is perceived as exemplary are also elevated to a persona in a metonymical move where the traits of the person are generalized into an ideal type, as when claiming that someone converted from "Hegel" to "Ranke." In these instances, the invocation of a name or a visual cue such as a portrait can serve as a shorthand for an entire approach to scholarship.

Naturally, instead of a wholesale acceptance of a prepackaged Ranke, scholarly communities were free to highlight different aspects of his work, method and

\footnotetext{
${ }^{2}$ Friedrich Meinecke, “Zur Beurteilung Rankes,” Historische Zeitschrift 111/3 (1913), 582-99, at 582.

${ }^{3}$ Iggers, "Image of Ranke," 12, 18.

${ }^{4}$ Lorraine Daston and H. Otto Sibum, "Introduction: Scientific Personae and Their Histories," Science in Context 16/1-2 (2003), 1-8; Herman Paul, "What Is a Scholarly Persona? Ten Theses on Virtues, Skills, and Desires," History and Theory 53/3 (2014), 348-71; Herman Paul, "Sources of the Self: Scholarly Personae as Repertoires of Scholarly Selfhood," Low Countries Historical Review 131/4 (2016), 135-54; Mineke Bosch, "Scholarly Personae and Twentieth-Century Historians: Explorations of a Concept," Low Countries Historical Review 131/4 (2016), 33-54. On a related concept see Ken Hyland, Disciplinary Identities: Individuality and Communality in Academic Discourse (Cambridge, 2012).

${ }^{5}$ Paul, "Sources of the Self," 152 f. See also Herman Paul, "The Virtues and Vices of Albert Naudé: Toward a History of Scholarly Personae," History of Humanities 1/2 (2016), 327-38, at 333.
} 
conduct and thus assemble multiple personae out of the wealth of one scholarly life. Carrying forward recent efforts to expand the study of scholarly personae beyond the German context, this article, then, explores how Japanese historians around the turn of the twentieth century went about fashioning "their" version of Ranke. ${ }^{6}$

\section{Reconsidering the notion of "Rankean historiography" in Japan}

This essay does not attempt to draw a complete picture of Ranke in Japan. Its starting point is a curious disparity: while Euro-American surveys of Japanese history writing in the nineteenth century have made strong claims about the impact of Rankean historiography, so far no attempt has been made to corroborate a substantial intellectual link between Ranke and Japanese historians. This introductory section discusses evidence that casts doubt on the presence of such a substantial link and introduces the particularities of the "Rankean moment" as an opportunity to rethink the notion of Rankean historiography through the lens of the scholarly persona.

What are meant by "substantial" here are the usual signs of intellectual engagement: first and foremost written output by historians reflecting on or influenced by Ranke's ideas and scholarship, attention to a variety of his publications and aspects of his work, translations and editions of his publications, and a sustained dialogue after initial contact. In post-1887 Japan, the year that is given as a starting date for Rankean historiography in Japan in the literature, none of these ingredients are present.

Euro-American accounts have asserted for decades that Ranke's methods were introduced to the archipelago by his disciple Ludwig Riess (1861-1928), who served as professor of Western history at the Imperial University in Tokyo from 1887 to 1902. ${ }^{7}$ The impact, we are told even in such recent accounts as Daniel Woolf's magisterial "Global History of History," was dramatic: "Any residual Chinese traditional influences on historiography were soon overwhelmed by Western scholarship ... Germany became the admired model." ${ }^{8}$ Yet, given the fact that Rankean thought is said to have entered Japan through Riess, it is remarkable

\footnotetext{
${ }^{6}$ Other recent case studies beyond the German context include Camille Creyghton, "Impartiality, Objectivity, and Political Engagement in Nineteenth-Century French Historiography: Monod and the Dreyfus Affair," History of Humanities 3/2 (2018), 279-302; Dawid Rogacz, "The Virtue of a Historian: A Dialogue between Herman Paul and Chinese Theorists of History," History and Theory 58/2 (2019), 252-67; and Hans Martin Krämer, "Orientalism and the Study of Lived Religions: The Japanese Contribution to European Models of Scholarship on Japan around 1900," in Christiaan Engberts and Herman Paul, eds., Scholarly Personae in the History of Orientalism, 1870-1930 (Leiden, 2019), 143-71; and many of the contributions in Herman Paul, ed., How to Be a Historian: Scholarly Personae in Historical Studies, 1800-2000 (Manchester, 2019).

${ }^{7}$ On Ludwig Riess's life and work in Japan see Madoka Kanai, Oyatoi gaikokujin 17: Jinbun kagaku (Tokyo, 1976), 107-97; Madoka Kanai, "Nihon no kindai akademii shigaku sodate no oya Riisu," in Kokuritsu kyōiku kaikan, ed., Kyōiku kōza shirizu 59: Nihon no kindaika o ninatta gaikokujin (Tokyo, 1992), 3-56; Kentarō Hayashi, "Ludwig Riess, einer der Väter der Geschichtswissenschaft in Japan," Bonner Zeitschrift für Japanologie 3 (1981), 31-45; Ulrich Goch, "Die Entstehung einer modernen Geschichtswissenschaft in Japan," Bochumer Jahrbuch zur Ostasienforschung 1 (1978), 238-71; Margaret Mehl, History and the State in Nineteenth-Century Japan (Basingstoke, 1998), 87-112; and Hartmut Walravens, "Zum publizistischen Wirken von Ludwig Rieß (1861-1928) in Japan und Deutschland: Ein Schriftenverzeichnis," Japonica Humboldtiana 20 (2018), 257-76.

${ }^{8}$ Daniel Woolf, A Global History of History (Cambridge, 2011), $429 \mathrm{f}$.
} 
how Riess is clearly of no intrinsic interest in these accounts. He is rarely introduced without the epithet "a disciple of Ranke," even though he had no more than a supporting role as scribe in the production of Ranke's late magnum opus on world history and supposedly conversed directly with the master only on two occasions. ${ }^{9}$ More often than not, Riess's name is even misspelled or his relation to Ranke otherwise misrepresented. ${ }^{10}$ In other words, the emphasis is clearly on Ranke, not on Riess.

Moreover, even a cursory review proves Ranke to be of much less concern to Riess's work in Tokyo than these accounts suggest. We know that Riess patterned his first lecture on world history after the structure of Ranke's eponymous magnum opus and continued to give the intermittent Ranke-related class. ${ }^{11}$ The notes to his lecture on the methodology of history give examples from Ranke's work, alongside that of numerous other historians from Johann Gustav Droysen and Henry Hallam to Bernard de Fontenelle. ${ }^{12}$ And one of Riess's students, Murakawa Kengo (18751946), later claimed that he "most enjoyed reading Ranke, adored his method of study, frequently quoted Ranke's works in his lectures and exercises at the university and thereby let us students appreciate Ranke's great historical knowledge." ${ }^{\prime 3}$ Likely, then, his students in Western, i.e. European and American, history in the 1890s were exposed to Ranke's name and status as an eminent historian in Europe, and perhaps also to some methodological principles and topics of his major works.

Yet, in Riess's publications and exchanges with his Japanese colleagues, Ranke barely featured at all. In his first contribution to the newly established Japanese Historical Journal in 1890, he duly invoked him as a "great authority," but without giving further details. ${ }^{14}$ In a biographical article for the Historical Journal six years

\footnotetext{
${ }^{9}$ Mehl, History and the State, 97.

${ }^{10}$ Some examples: "The Japanese historians who received scientific method [sic], by way of Ranke's disciple, Ludwig Riess." John S. Brownlee, Japanese Historians and the National Myths, 1600-1945: The Age of the Gods and Emperor Jinmu (Vancouver, 1997), 74. "The first of these Meiji approaches could claim a loose genealogical link with Leopold von Ranke. In 1887, one of von Ranke's students, Ludwig Reiss $[s i c]$, was invited $\ldots$ to teach history ... Reiss's approach ... impressed Japanese historians." Julia Adeney Thomas, "High Anxiety: World History as Japanese Self-Discovery," in Benedikt Stuchtey and Eckhart Fuchs, eds., Writing World History, 1800-2000 (Oxford, 2003), 309-26, at 316. "the history department (shigakka) was founded and a young German historian (a distant student of Leopold von Ranke), Rudolph [sic] Riess, hired." Axel Schneider and Stefan Tanaka, "The Transformation of History in China and Japan," in Stuart Macintyre, Juan Maiguashca and Attila Pók, eds., The Oxford History of Historical Writing, vol. 4, 1800-1945 (Oxford, 2011), 491-519, at 499. "From the 1880s, students [sic] of Leopold von Ranke came to Japan and helped create the department of history at Tokyo Imperial University." Curtis Anderson Gayle, "The World of Modern Japanese Historiography: Tribulations and Transformations in Historical Approaches," in Prasenjit Duara, Viren Murthy and Andrew Sartori, eds., A Companion to Global Historical Thought (Malden, 2014), 213-27, at 215.

${ }^{11}$ See Riess's letter to Hans Delbrück, dated 24 June 1887, reprinted in Japanese in Yōichi Nishikawa, "Berurin kokuritsu toshokan shozō Rūtovihi Riisu shokan ni tsuite," Kokka gakkai zasshi 115/3-4 (2002), 179-223, at 189. Kanai, Oyatoi gaikokujin, 144, relates that Riess later lectured on Ranke's History of England as well.

${ }^{12}$ Ludwig Riess, Methodology of History (Tokyo, n.d.).

${ }^{13}$ Kengo Murakawa, preface to Leopold von Ranke, Sekaishiron shinkōroku, trans. Kengo Murakawa (Tokyo, 1918), 1.

${ }^{14}$ Ludwig Riess, "Shigakkai zasshi hensan ni tsukite iken," Shigakkai zasshi 1/5 (1890), 1-14, at 13.
} 
later, Riess commemorated Ranke's successor at the university in Berlin, Heinrich von Treitschke, who had passed away earlier that year; he never penned a comparable article on Ranke. ${ }^{15}$ In 1901, right in the middle of the Rankean moment, in a letter to his former teacher, Hans Delbrück, in Berlin, he even openly mocked the notion of a Rankean school of historiography proposed by German historians Kurt Breysig and Karl Lamprecht as a "fairytale." 16

What this suggests is that Riess should perhaps only be called a "Rankean" in the sense that he had studied in Berlin under Ranke's successors, who "continued the tradition" of "historical methods taught by Ranke."17 This, however, is precisely the kind of ascription that blurs the distinction between Ranke's research and methodology and Ranke as a persona which is at issue here. For good reason, then, Japanese accounts, while giving full credit to Riess's presence, are much more hesitant to mention Ranke's name, much less assert a transformative Rankean impact on Japanese historiography. ${ }^{18}$

If many of the survey articles are rather indifferent about Riess, they show even less concern for the Japanese scholars that supposedly embraced Ranke: Riess's colleagues at the Imperial University, Tsuboi Kumezō (1858-1936) and Mitsukuri Genpachi (1862-1919), who were of roughly the same age and had both also studied in Germany, are hardly ever mentioned in survey texts. ${ }^{19}$ In 1894, Tsuboi, lecturer in history since 1886 and Riess's colleague in the department of Western history since 1891, situated Ranke in an essay "On History" at the starting point of "pure [scientific] history" but did not explicate this theme any further. ${ }^{20}$ This is the only context in which either of them mentioned Ranke before around the year 1900 .

Despite the alleged paradigm shift and Riess's invocations, it took Japanese historians quite some time to develop a more than passing interest in Ranke. When it finally materialized, Riess's tenure was already in its twelfth year and scholars had been studying various strands of Euro-American historiography for several decades. It was only around 1900 that Ranke rather abruptly acquired the status of a celebrity. Within the short span of four years, a heightened interest welled up in different venues of the emerging academic discipline. The flagship Historical Journal opened

\footnotetext{
${ }^{15}$ Ludwig Riess, "Hainrihi fon Toraichuke," Shigaku zasshi 7/8 (1896), 1-8.

${ }^{16}$ See Ludwig Riess's letter to Hans Delbrück dated 14 June 1901, reprinted in Japanese in Nishikawa, "Rūtovihi Riisu shokan ni tsuite," 212.

${ }^{17}$ Mehl, History and the State, 97.

${ }^{18}$ Key Japanese-language works on Japanese historiography that include a discussion of the late nineteenth century are Toshiaki Ōkubo, Nihon kindai shigakushi (Tokyo, 1940); Eiichi Ozawa, Kindai nihon shigakushi no kenykū: Meiji hen (Tokyo, 1968); Keiji Nagahara, 20 seiki nihon no rekishigaku (Tokyo, 2003). Cf. also the essays in the anthology Eiichi Matsushima, ed., Meiji shironshū, 2 vols. (Tokyo, 1965-7). In all of these works, Ranke's name appears mainly in prefaces and endnotes. The boldest assertion I found, made by Nagahara (at 35), is that the Japanese historian Shigeno Yasutsugu's "strong belief in impartiality" was possibly "boosted further by Ranke's historicist recognition of 'what actually happened', which he learned from Riess."

${ }^{19}$ In the sole substantial biographical note on Mitsukuri, the author deemed it of consequence to speculate about whether he could have met Ranke, even though Mitsukuri arrived in Germany (not even in Berlin) only one year before his death. Eiichi Matsushima, "Mitsukuri Genpachi," in Keiji Nagahara and Masanao Kano, eds., Nihon no rekishika (Tokyo, 1976), 63-9, at 66.

${ }^{20}$ Kumezō Tsuboi, "Shigaku ni tsukite," Shigaku zasshi 5/1 (1894), 9-19, at 13.
} 
with a photographic portrait and a fervent eulogy, Japanese historians wrote articles on his method, and students of the Imperial University organized a symposium commemorating his life and achievements.

This phenomenon shall be called a "Rankean moment" here, for two reasons. First, it was intellectually circumscribed in the sense that it was mostly based on a rather superficial familiarity with Ranke's thought and oeuvre: statements about Ranke's stature in Germany and Europe known to and eventually reproduced by Tsuboi, Riess and Mitsukuri, and references to the first lecture of Ranke's "On the Epochs of Modern History" and the preface written by his publisher, Alfred Dove. Second, it ended as abruptly as it began. Only after a considerable hiatus were further articles on Ranke's thought and the first Japanese translation of one of his works published. ${ }^{21}$ The most significant contribution on Ranke's thought before 1945, Kyoto University historian Suzuki Shigetaka's treatise on Ranke's view of world history, published roughly four decades later, did not even acknowledge the discussions of the Rankean moment, even though these were centrally concerned with Ranke as a world historian. ${ }^{22}$

While both the lack of evidence for previous engagement and the nature of the Rankean moment are hard to reconcile with earlier accounts of Ranke's impact in Japan, the notion of the scholarly persona offers a different explanation. By shifting the focus away from intellectual lineages and towards models of scholarly virtue, it allows us to conceptualize the Rankean moment as a culmination of the search for models of the good historian that had occupied Japanese scholars since the late 1870 s.

\section{The transformation of historical scholarship and the search for models}

Even before Ludwig Riess arrived in Tokyo, history writing in Japan had long been a "crowded discursive field." ${ }^{23}$ Already the last decades of the 1700s saw a surging interest in national history, an import of new methodologies of evidential scholarship from China, and an intensification of what might be termed Western area studies. ${ }^{24}$ In the mid-nineteenth century, history became a means to make sense

\footnotetext{
${ }^{21}$ A list of editions Ranke's works and critiques of Ranke compiled by University of Tokyo graduate Nonomura Kaizō in the wake of the Rankean moment gives the articles by Riess and Mitskuri discussed below as the only Japanese contributions. See Kaizō Nonomura, Shoko nisshō (Tokyo, n.d.), 37. Among the later contributions are Genpachi Mitsukuri, "Rekishika no taito Ranke," Gakusei 4/10 (1913), 35-42, republished in Mitsukuri, Seiyō shiwa (Tokyo, 1915), 581-91; and Yoichi Ichimura, "Ranke no rekishikan," Tōyō tetsugaku 21/3 (1914), 1-14. The first Japanese translation is Ranke, Sekaishiron shinkōroku.

${ }^{22}$ Shigetaka Suzuki, Ranke to sekai shigaku (Tokyo, 1939). Suzuki's discussion was based on post-World War I German-language Ranke scholarship and Friedrich Meinecke's discussion of the so-called crisis of historicism. See also Jun Sugawara, “Kindai no chōkoku' saikō (sono 1): 'Sekaishiteki tachiba to nihon' to no taihi," Nagasaki daigaku sōgō kankyō kenkyū 9/2 (2007), 33-40.

${ }^{23}$ Thomas Keirstead, "Shigaku/History," Working Words: New Approaches to Japanese Studies series (2012), http://escholarship.org/uc/item/32t6g8nf, 3.

${ }^{24}$ For a survey of the main historiographical traditions in the early modern period see Masayuki Sato, "A Social History of Japanese Historical Writing," in José Rabasa, Masayuki Sato, Edoardo Tortarolo and Daniel Woolf, eds., The Oxford History of Historical Writing, vol. 3, 1400-1800 (Oxford, 2012), 80-102; W. G. Beasley and Carmen Blacker, "Japanese Historical Writing in the Tokugawa Period," in W. G. Beasley and E. G. Pulleyblank, eds., Historians of China and Japan (London, 1961), 245-63; and
} 
of the escalating internal and external political crisis and discuss the future form of the Japanese polity. ${ }^{25}$ With the opening of the ports after 1854, Japanese intellectuals intensified their studies and translation efforts of Western historical works. They were especially intrigued by the civilizational histories in the style of François Guizot and Henry Thomas Buckle, as the idea of the progress of civilization afforded them a new understanding of Japan's political trajectory and place in the world. ${ }^{26}$ While not historical writing per se, Herbert Spencer's publications and his social Darwinist views of human development were also widely absorbed by Japanese intellectuals. ${ }^{27}$

The broader cultural and political changes of the Meiji period (1868-1912) shook up received notions of the purpose of history writing and its position in the wider field of scholarship. On the institutional level, history had not been a clearly delineated field of learning in the Tokugawa period (1600-1868)-boundaries between history and philology, literature, morality and politics were often vague. At the forerunner of the Imperial University in Tokyo, for example, history was taught as part of the English, law and philosophy curricula as well as in courses in Japanese and Chinese classics. Dedicated historical departments were only set up from the late 1880s: the History Department, where Ludwig Riess was appointed first professor, was created in 1887; the Historiographical Office, which had been tasked with an official dynastic history by the Meiji government, was attached to the university as the Historiographical Institute in 1889, with a dedicated department for national history being added the following year and a unit for history and geography, which in practice focused on European and American history, in

Kate Wildman Nakai, "Tokugawa Confucian Historiography: The Hayashi, Early Mito School, and Arai Hakuseki," in Peter Nosco, ed., Confucianism in Tokugawa Culture (Princeton, 1984), 62-91. On national history see Takeshi Yamashita, "Wagaku kōdansho no jittai," Nihon no kyōiku shigaku 4 (1961), 62-87; Tarō Sakamoto, "Wagaku kōdansho ni okeru henshū shuppan jigyō," Nihon rekishi 194 (1964), 3-14; Kyōko Ikeda, "Hanawa Hokiichi to wagaku kōdansho ni kansuru ikkōsatsu: Wagaku kōdansho setsuritsu no haikei to Hanawa Hokiichi no ishiki kōzō o chūshin ni," Onko sōshi 59 (2005), 28-75. On evidential scholarship see Benjamin A. Elman, "The Search for Evidence from China: Qing Learning and Kōshōgaku in Tokugawa Japan," in Joshua A. Fogel, ed., Sagacious Monks and Bloodthirsty Warriors: Chinese Views of Japan in the Ming-Qing Period (Norwalk, 2002), 158-84. On scholarship based on Dutch materials see Jirō Numata, Western Learning: A Short History of the Study of Western Science in Early Modern Japan (Tokyo, 1992), 80-160; Terrence Jackson, Network of Knowledge: Western Science and the Tokugawa Information Revolution (Honolulu, 2016); and Donald Keene, The Japanese Discovery of Europe, 1720-1830 (Stanford, 1969).

${ }^{25}$ The most influential work in this context is Rai San'yō's "Unofficial History of Japan" (Nihon gaishi). See Seiichirō Hamano, Rai San'yō no shisō: Nihon ni okeru seijigaku no tanjō (Tokyo, 2014). On the political history of late early modern Japan see Andrew Gordon, A Modern History of Japan: From Tokugawa Times to the Present, 3rd edn (Oxford, 2014), 10-59.

${ }^{26}$ Carmen Blacker, The Japanese Enlightenment: A Study of the Writings of Fukuzawa Yukichi (Cambridge, 1964), 90-100; Peter Duus, "Whig History, Japanese Style: The Min'yūsha Historians and the Meiji Restoration," Journal of Asian Studies 33/3 (1974), 415-36; Shingo Minamizuka, "Kindai nihon no 'bankokushi'," in Shigeru Akita, Yōko Nagahara, Masashi Haneda, Shingō Minamizuka, Akimasa Miyake and Shirō Momoki, eds., "Sekaishi" no sekaishi (Kyoto, 2016), 293-320; Toru Takenaka, "The Domestication of Universal History in Meiji Japan: Fukuzawa Yukichi and Nakae Chōmin," Saeculum 63/1 (2013), 119-42.

${ }^{27}$ Douglas Howland, "Society Reified: Herbert Spencer and Political Theory in Early Meiji Japan," Comparative Studies in Society and History 42/1 (2000), 67-86; Michio Nagai, "Herbert Spencer in Early Meiji Japan," Far Eastern Quarterly 14/1 (1954), 55-64. 
1891; Chinese history was formally separated from literature and language studies even later, in the years between 1897 and 1910, when it merged into the department for oriental history. ${ }^{28}$

The new institutional frameworks engendered by the extensive reform programs of the Meiji government made it necessary to reflect on new models of scholarship. Scholars who had been socialized to follow the model of the Confucian scholarofficial, the dominant persona of the Tokugawa period, were abruptly turned into professional historians working in the context of university departments based on notions of academic disciplines that had not previously existed in this form in Japan. ${ }^{29}$ How to fill out the new institutional role of the professional academic historian consequently became a central task for this generation of scholars.

One early attempt to find new models was carried out by the Historiographical Office. In 1879, it commissioned the Hungarian scholar Gustav Zerffi to produce a survey of European historiographical traditions. ${ }^{30}$ His instructions were couched in a language of traits and virtues that is a key feature of scholarly personae: to state "the personal qualifications necessary in a historian"; to "enumerate those great authors who, by the common consent of mankind, have realized the ideal of what a Historian should be; and show, how the Historian of the present day should familiarize himself with the principles which guided them, and with the methods which they followed, if he himself too should desire to attain similar excellence." Zerffi was explicitly told to "enumerate and criticize the greatest modern Historians, whether English, French, or German \&c."31 And so he did, allotting about a 150 pages to the recent centuries of European historiography. Ranke appeared only in passing, in a row with other influential German historians such as Barthold Georg Niebuhr, Theodor Mommsen and Heinrich von Sybel. ${ }^{32}$ The result did not turn out to be what the institute expected, however, as Zerffi had focused on the philosophy of history and ancient Greek authors at the expense of contemporary standards and exemplars of the discipline, and ended up having only limited impact on subsequent debates. ${ }^{33}$

Such debates proliferated in the following years, as the new class of professional academic historians attempted to define their role and purpose, discussing scholarly virtues like impartiality, diligent textual criticism or the emancipation of history from Confucian notions of morality. ${ }^{34}$ As these discussions were centrally about

\footnotetext{
${ }^{28}$ See Tōkyō teikoku daigaku, ed., Tōkyō teikoku daigaku gakujutsu taikan: Sōsetsu bungakubu (Tokyo, 1942), 309-22; Mehl, History and the State, 87-112; Tōkyō daigaku hyakunen shi henshū iin kai, ed., Tōkyō daigaku hyakunen shi: Bukyoku shi 1 (Tokyo, 1986), 607-86.

${ }^{29}$ Cf. John W. Hall, "The Confucian Teacher in Tokugawa Japan," in David S. Nivison and Arthur F. Wright, eds., Confucianism in Action (Stanford, 1959), 268-301.

${ }^{30} \mathrm{Mehl}$, History and the State, 71-80.

${ }^{31} \mathrm{~K}$. Suematsu, "Instructions", preface to Gustav Zerffi, The Science of History (London, 1879), ix-xiii, at ix.

${ }^{32}$ Zerffi, Science of History, 767.

${ }^{33} \mathrm{Mehl}$, History and the State, 71-80.

${ }^{34}$ Impartiality: Yasutsugu Shigeno, "Shigaku ni jūji suru mono wa sono kokoro shikō shihei narazaru bekarazu," in Toshiaki Ōkubo, ed., Zōtei Shigeno Yasutsugu hakushi shigaku ronbunshū. Jōkan (Tokyo, 1989), 30-33; textual criticism: Yasutsugu Shigeno, "Gakumon wa tsui ni kōshō ni kisu," in Toshiaki Ōkubo, ed., Zōtei Shigeno Yasutsugu hakushi shigaku ronbunshū. Jōkan (Tokyo, 1989), 35-47; morality: Brownlee, Japanese Historians, 80.
} 
professional disciplinary virtues in history writing, they were led freely across the emerging, but still vague, geographical subfields of national, Western and oriental history, as evidenced by the term akademizumu ("academism") that Japanese historians retroactively applied to the mainstream of academic pre-World War II history. ${ }^{35}$

Concurrently with the establishment of an academic historiography, there emerged a group of popular history writers, often called Min'yūsha historians after the platform and publishing house of the same name, who consciously defined the purpose of history in opposition to the new disciplinary standards. Just as academic historians employed virtue language to distinguish "professionals' from 'amateurs"' and discredit the latter as "pseudo-historians," ${ }^{36}$ these writers attacked their academic counterparts for having traded vitality and relevance for rigor and accuracy in their pursuit of historical facts. ${ }^{37}$ Instead they cherished Buckle, Guizot and Spencer and their notions of "laws" and "principles" in history. ${ }^{38}$ As with these authors, history for the Min'yūsha historians linked up with politics as they construed such laws to guide societies along a historical path to ever greater freedom and progress.

It is not surprising, then, that they found a model of the exemplary historian in the British politician and paradigmatic Whig historian Thomas Macaulay (180059). The popular history journal Shikai featured a biographical sketch of Macaulay in 1892, and one of the Min'yūsha historians, Takekoshi Yosaburō, published a longer stand-alone biography a year later. ${ }^{39}$ For Takekoshi, the most outstanding virtues of Macaulay were his lively and absorbing narrative style and the fact that he brought to bear his insight as a statesman on his writing. ${ }^{40}$ The opposition between academic and popular approaches to history writing around 1890 is mirrored in the way their respective proponents discussed scholarly virtues: while the Min'yūsha writers favored biography and a persona based on an individual historian, the academic historians at that time preferred theoretical reflection on abstract virtues. It was only once the new institutional forms had taken root, around the turn of the century, that academic historians unexpectedly discovered a comparable human vessel that could personify the ideal constellation of virtues that they had been pursuing-in Leopold von Ranke.

\section{Ranke's virtues}

The kickoff for the Rankean moment in Japan was a set of articles in the Historical Journal. This journal was published by the Historiographical Society, which was founded in 1889 as a professional organization for academic historiography on

\footnotetext{
${ }^{35}$ On akademizumu see Mehl, History and the State, 103-12. On the discursive field of Oriental history see also Stefan Tanaka, Japan's Orient: Rendering Pasts into History (Berkeley, 1993).

${ }^{36}$ Paul, "Virtues and Vices," 333.

${ }^{37}$ Margaret Mehl, "The Mid-Meiji 'History Boom': Professionalization of Historical Scholarship and Growing Pains of an Emerging Academic Discipline," Japan Forum 10/1 (1998), 67-83, at 76.

${ }^{38}$ Duus, "Whig History, Japanese Style," 417.

${ }^{39}$ Shinsaku Yabe, "Tōmasu Makōrei," Shikai 15 (1892), 27-45; Yosaburō Takekoshi, Makouree (Tokyo, 1883).

${ }^{40}$ Hiroshi Imai, "British Influence on Modern Japanese Historiography," Saeculum 38/1 (1987), 99-112, at $109 \mathrm{f}$.
} 


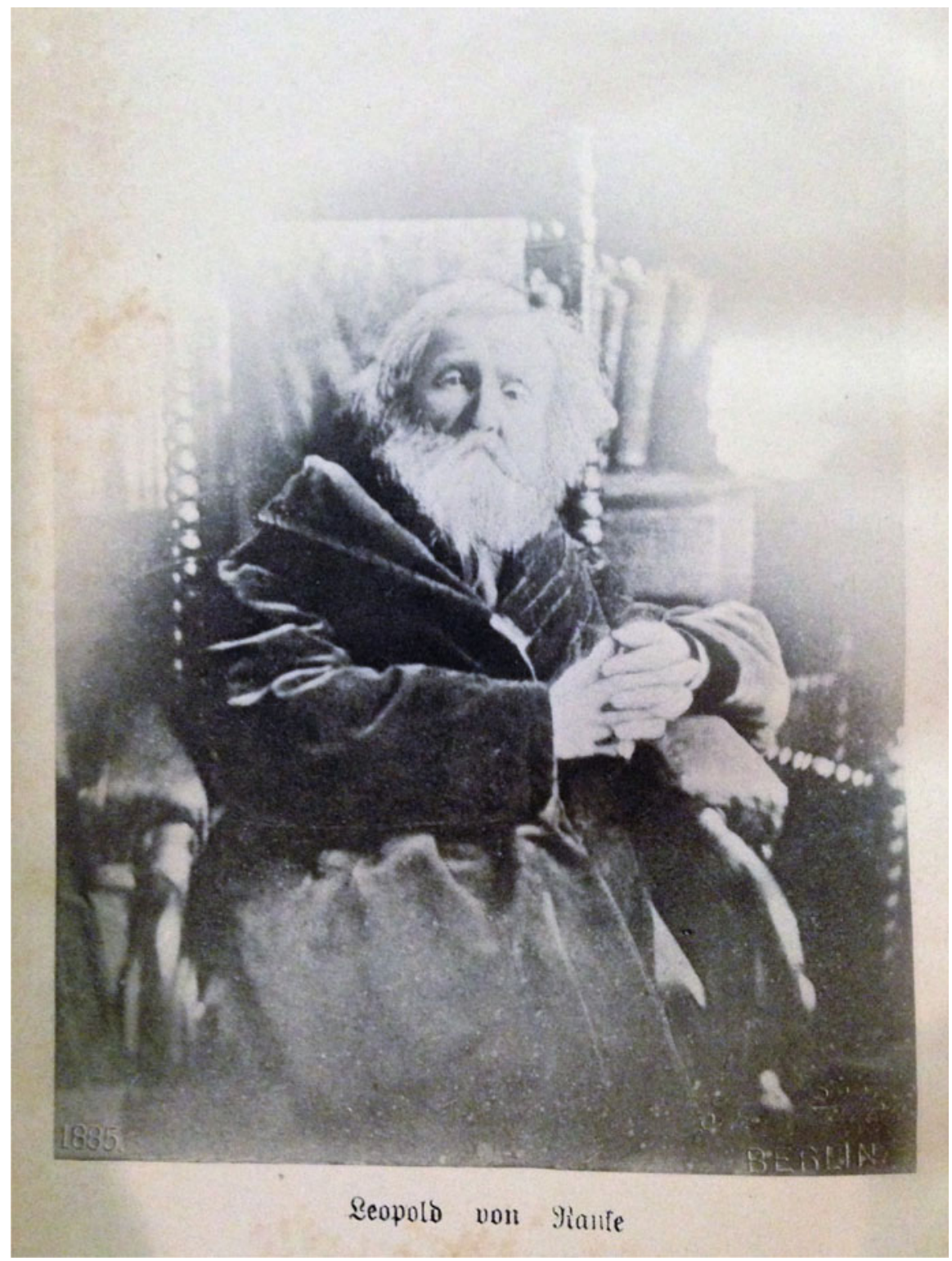

Fig. 1. A portrait of Leopold von Ranke around his ninetieth birthday, reprinted in Shigaku zasshi 10/1 (1899).

the initiative of Ludwig Riess and his colleague at the Historiographical Institute Shigeno Yasutsugu (1827-1910). ${ }^{41}$ For the January 1899 issue, Murakawa Kengo, a recent graduate and at that time editor of the journal, planned to feature a portrait of Ranke as part of the front matter (Fig. 1) and requested that Riess write an

\footnotetext{
${ }^{41}$ Mehl, History and the State, 96.
} 
appraisal to supplement the photograph. Riess's contribution is a useful case study for the construction of a scholarly persona: instead of sketching out Ranke's life and career or summarizing his most influential works, it condenses him into a list of generalizable character traits and accomplishments. Priming his readers for such an approach, Riess declared that "the worth of a historian resides in various dispositions" and then familiarized them with Ranke's unprecedented range of beneficial scholarly dispositions, the presence of which warranted, in Riess's eyes, the epithets "easily the best" and "the greatest historian of all times." ${ }^{2}$ Riess's manner of presentation was to introduce a general category-a scholarly virtue-and show how Ranke embodied it with bravura, an illustration of the metonymical move by which the traits of an individual can be abstracted into a persona. These are the eight virtues that Riess enumerated:

1 the discovery and systematical use of new sources,

2 methodical source criticism,

3 the development of an interpretation based on the sources,

4 an adeptness at lively written portrayal,

5 a wide range of research topics,

6 the ability to write about contemporary history,

7 an excellent command of prose writing and

8 the ability to explain the advancement of civilization.

What is noteworthy here is that an aspect that played a major role in European and American discussions of Ranke's virtues and is still associated with his name today is absent: his aspiration to objectivity and impartiality. In contrast, the ability to write about current events and to explain the advancement of civilization are two dispositions not commonly encountered in Western accounts of Ranke's qualities. In part, these priorities seem to be based in Riess's personal notions of the skillful historian: his explanation of Ranke's "wide range of research topics" in terms of geographical breadth betrayed his personal inclination towards universal and world history. ${ }^{43}$

At any rate, Riess's version of Ranke's virtues resonated with his Japanese audience. Contemporary relevance and explanatory power in the realm of the global race for civilization were two core concerns of Japanese historiography in the late nineteenth century. The analysis of civilizational progress in a global framework to understand and advance Japan's place in the world had been a central challenge for the civilizational histories prominent in the 1870s and 1880s and continued to

\footnotetext{
${ }^{42}$ Ludwig Riess, "Kūzen zetsugo no saidai shika," Shigaku zasshi 10/1 (1899), n.p.

${ }^{43}$ "Next to his work on world history, he has produced a wide-ranging body of books on Germany, Prussia, France, Italy, England, the Ottoman Empire, Spain, and the Papal State." Ibid, n.p. Riess is said to have loved world history already as a child. Kanai, Oyatoi gaikokujin, 136. He wrote his doctoral dissertation under Hans Delbrück, who attempted a "universalist approach" to history. Mehl, History and the State, 98. He gave lectures in universal history in Tokyo, and he published a revised version of a world history by Georg Weber. Ludwig Riess, A Short Survey of Universal History: Being Notes of a Course of Lectures Delivered in the Literature College of the Imperial University of Tokyo (Tokyo, 1899); Günter Johannes Henz, Leopold von Ranke in Geschichtsdenken und Forschung, vol. 1, Persönlichkeit, Werkentstehung, Wirkungsgeschichte (Berlin, 2014), 359.
} 
inform the outlook and priorities (if not the narrative forms) of state-funded academic historiography in the 1890 s. $^{44}$ The short eulogy was thus a first step towards a Rankean persona retrofitted for Japanese purposes.

It is fortunate for our understanding of Ranke's place in late Meiji Japan that, later that year, the Historical Journal also published the first contribution by a Japanese scholar on Ranke to complement Riess's eulogy: Mitsukuri Genpachi's short article on "Ranke's Method of Historical Research." ${ }^{45}$ Mitsukuri, who was nearly the same age as Riess, had studied in Tübingen (where he also received his doctorate), Heidelberg and Berlin between 1885 and 1892. Upon his return to Japan, he was appointed professor at the Tokyo Higher Normal School and taught classes in Western history at Tokyo Imperial University before replacing Riess as professor of Western history in 1902. ${ }^{46}$ Mitsukuri's article demonstrates that he was well versed in the currents of German historiography: he pointed out Ranke's indebtedness to Barthold Georg Niebuhr, and gave the original terms for Ranke's methods and two extensive quotes in German-one of them, by Ottokar Lorenz, with misspellings and grammatical errors ("Immer und überall erscheint uns Ranke wie der König der Histriographie"), but Mitsukuri seemingly was the only one with sufficient knowledge of German at the time, as the editors failed to notice. His familiarity with Ranke likely stemmed from his association with Max Lenz, since 1890 professor in Berlin, who had styled himself an "epigone of Ranke" and "Neo-Rankian."

Following a taxonomy directly taken from Alfred Dove's preface to Ranke's "On the Epochs of Modern History," Mitsukuri first sketched three methodological principles employed by Ranke-the antiquarian, combining and philosophical methods-and stressed his accomplishments in all of them. ${ }^{48} \mathrm{He}$ then praised Ranke's imagination, quoting Max Lenz, who had compared his literary qualities to those of Johann Wolfgang von Goethe. At first glance, it thus seems as if

\footnotetext{
${ }^{44}$ Ozawa, Kindai nihon shigakushi; Nagahara, 20 seiki nihon no rekishigaku, 19-31; Toshiaki Ōkubo, "Meiji jidai ni okeru rekishi riron," Rekishi kyōiku 4/3 (1956), 31-8; and Toshiaki Ōkubo, "Meiji shigaku seiritsu no katei," Rekishigaku kenkyū 105 (1942), 2-30.

${ }^{45}$ Genpachi Mitsukuri, "Ranke no rekishi kenkyū hō ni tsukite," Shigaku zasshi 10/6 (1899), 36-45.

${ }^{46}$ Research on Mitsukuri's life and work is scarce. Apart from two contributions on his travel diary in Europe, we only have two short biographical notes, and recently an article on his textbooks on Western history, all in Japanese. On the diaries see Eiichi Matsushima, "Mitsukuri Genpachi no 'zaidoku nikki' ni tsuite: Kindai nihon shigakushi no hitokoma," Shikan 61 (1961), 24-43; Fumiko Ide and Michio Shibata, Mitsukuri Genpachi taiō "fukubai nikki" (Tokyo, 1984). Biographical notes: Matsushima, "Mitsukuri Genpachi"; Kenji Yamanaka, "Mitsukuri Genpachi sensei: Seiyō shikai no senkusha (4)," Rekishi kyōiku 13/6 (1965), 73-4. Textbooks: Heitarō Yamagawa, "Mitsukuri Genpachi to kyūsei chūgaku seiyōshi kyōkasho," Kōchi daigaku kyōiku gakubu kenkyū hōkoku 76 (2016), 225-32.

${ }^{47}$ Max Lenz, Die großen Mächte: Ein Rückblick auf unser Jahrhundert (Berlin, 1900), 6. For an evaluation of Lenz's "neo-Rankeanism" see Henz, Leopold von Ranke, 1: 387-90; and Hans-Heinz Krill, Die Rankerenaissance: Max Lenz und Erich Marcks. Ein Beitrag zum historisch-politischen Denken in Deutschland, 1880-1935 (Berlin, 1962). See also Ludwig Dehio, "Ranke und der deutsche Imperialismus," in Dehio, Deutschland und die Weltpolitik im 20. Jahrhundert (Frankfurt am Main, 1961), 33-62; and Charles E. McClelland, "Berlin Historians and German Politics," Journal of Contemporary History 8/3 (1973), 3-33.

${ }^{48}$ Cf. Alfred Dove, "Vorwort," in Leopold von Ranke, Weltgeschichte. Neunter Teil, zweite Abtheilung: Über die Epochen der neueren Geschichte. Vorträge dem Könige Maximilian II. von Bayern gehalten, ed. Alfred Dove (Leipzig, 1888), v-xxvi, at xi.
} 
Mitsukuri rehearsed in more detail the points already present in Riess's eulogy. Half of the article, however, was devoted to an aspect of Ranke's work that was, and is still today, rarely seen as one of his major contributions to the historical discipline: his unfinished multivolume world history. ${ }^{49}$ Quoting from Ranke's lectures for the Bavarian king Maximilian, Mitsukuri eschewed the well-known historicist credo that "every age is next to God." Instead he emphasized a part where Ranke, while conceding that he could never surpass the greatness of Thucydides and the ancients, was hopeful that he could achieve "something else"-for the reason that "our history flows more profoundly than theirs, because we seek to draw other potencies into history that encompasses the life of all nations, in a word, because we seek to grasp history as a unity." This is what Mitsukuri took to be the essence of Ranke's "philosophical method": "to understand the history of the world as a unity and take a broad overview from the whole ... In other words, it is the ultimate goal of the historian to learn the actual conditions of how and in which direction mankind has been progressing." 50

It is quite obvious that this idea of progress and the development of civilization, while mirroring two of the virtues mentioned by Riess, is not in Ranke's original text. In fact, it directly contradicted Ranke's convictions as explicated in the very treatise Mitsukuri was quoting. Ranke was unambiguous about his rejection of the idea of historical progress, declaring it an "empty claim." 51 Still, as explained above, the notion that the contemporary world was marked by a competition for the highest standard of civilization, rooted in the concrete experience of Western imperialism, had been fundamental to the worldview of Japanese intellectuals for several decades. History, among other things, had to serve the role of explaining the origins of the contemporary world and the state of global politics. To be able to do so, it needed a universal purview.

We can trace back how Mitsukuri read this idea into the original text through his Japanese translation of the German quote. "Because our history flows more profoundly," originally a question of intensity, turns into "because the area of our history is wider than that of the ancients," a statement of greater geographical expanse. $^{52}$ This, again, echoed Riess's eulogy, which had stressed the geographical breadth of Ranke's research. Mitsukuri turned this global perspective into a scholarly virtue by linking it to the analytical pretensions of history as a science, in the wider nineteenth-century sense of the word. The claim to universal applicability and explanatory power had made the idea of science attractive to Japanese scholars, as it matched their new experience of the world as a global totality and promised a method to comprehend it. This is one of the recurring themes in Japanese discussions of science in this period, and history, too, had to comply with this

\footnotetext{
${ }^{49}$ See Juhnke, Leopold Ranke, 197-224. On Ranke's thought on world history see Eberhard Kessel, "Rankes Idee der Universalhistorie," Historische Zeitschrift 178/1 (1954), 269-308; and Ernst Schulin, "Universalgeschichte und Nationalgeschichte bei Leopold von Ranke," in Mommsen, Leopold von Ranke und die moderne Geschichtswissenschaft, 37-71.

${ }^{50}$ Mitsukuri, "Ranke no rekishi kenkyū hō," 42.

${ }^{51}$ Ranke, Über die Epochen der neueren Geschichte, 3.

52 "Weil unsere Historie voller strömt" versus "wareware no rekishi wa kojin no rekishi yori mo kuiki hirokereba nari." Mitsukuri, "Ranke no rekishi kenkyū hō," 41 f.
} 
standard. ${ }^{53}$ For Mitsukuri, to inhabit a global perspective like Ranke was an essential ingredient for a scientific approach to history and thus a good every historian should strive after: "No matter how minute a historical fact we might be investigating, not for a single moment must we forget to keep this big picture in mind. To the extent that we fail to do so and research historical facts as individual things, history cannot enter the sphere of science." ${ }^{54}$

Fascinatingly, Mitsukuri had already made the case for global history three years earlier in remarkably similar words, without connection to Ranke, in a speech at the Japanese Conference for Education:

Scientific history means world history. Countries are connected to each other, and world history means to determine ... how they influence one another, in other words, how human [society] has been progressing. When we talk about the parts of world history, we need to consider even small things in a single country. After all, one small thing can have a big impact on the history of this country, and if it influences one country, it likewise has an influence on the whole ... Insofar that it pursues truths about the history of the whole, that is, of the world, this is undeniably a science. ${ }^{55}$

This confirms that Mitsukuri had identified a global perspective as an epistemic virtue first and only later came to see Ranke as an embodiment of this virtue.

It is crucial to take note of this Japanized version of the Ranke persona both from a conceptual interest in the scholarly persona and from an interest in the global history of historiography. On the one hand, Riess's and Mitsukuri's views of Ranke demonstrate the malleability of virtues: even though they were derived from a concrete historian, many different interpretations were possible. They also serve to highlight how Ranke's image and virtues, which according to the established narrative radiated outward to a Japanese audience from Germany, were in fact from the beginning filtered through a Japanese worldview.

\section{Criticism at the Ranke Festival}

The confidence of Japanese scholars vis-à-vis Ranke was even more apparent in the "Ranke Festival" that took place on 20 December 1903 at Tokyo Imperial University in celebration of Ranke's 108th birthday. The festival started at one o'clock in the afternoon with a succession of commemorative speeches and was followed by a

\footnotetext{
${ }^{53}$ On the idea of science in late nineteenth-century Japan see Kunihisa Morita, "Kindai kagaku no kigen: Honshitsu o tankyū suru gaku to shite no kagaku," in Tarō Iida and Kazuhiro Fujimaki, eds., Kindai gakumon no kigen to hensei (Tokyo, 2014), 201-21; James R. Bartholomew, "Modern Science in Japan: Comparative Perspectives," Journal of World History 4/1 (1993), 101-16. On the relationship between science, technology and nation building see Tessa Morris-Suzuki, The Technological Transformation of Japan: From the Seventeenth to the Twenty-First Century (Cambridge, 1994), 71-160; David Wittner, Technology and the Culture of Progress in Meiji Japan (Milton Park, 2008); Hiromi Mizuno, Science for the Empire: Scientific Nationalism in Modern Japan (Stanford, 2009), 1-68.

${ }^{54}$ Mitsukuri, "Ranke no rekishi kenkyū hō," 42.

${ }^{55}$ Genpachi Mitsukuri, "Seiyō rekishi kyōju hō ni kansuru hiken," Dai nihon kyōikukai zasshi 176 (1896), 10-23, at 11 .
} 
relaxed get-together with food and drinks that continued into the evening. ${ }^{56}$ Among the fifty-nine participants there were many students and young scholars such as Murakawa Kengo, but also the professors of the department, Mitsukuri and Tsuboi.

A day of speeches and fond recollection of the great master's achievements in the shadow of his portrait, below which "many dozen volumes of his peerless masterpieces were arranged" and which was fittingly "decorated with two twigs of laurel" on top and chrysanthemums and "traditionally Japanese bonsai" in front ${ }^{57}$ : at first glance, the festival suggests that Japanese historians had finally become infected by the "typically German fervor of hero worship." ${ }^{38}$ This was certainly the impression gained by the German ambassador to Japan when he heard of the event. "I thank you, esteemed professor," he wrote to the organizer, Takakuwa Komakichi, "for this honorable commemoration of the German historian and master of historical criticism. I will see to it that this interesting and touching scholarly congregation will also be taken note of in my home country." 59

A closer examination reveals that the festival had a more substantial agenda. For all the good-willed commemoration that took place, the speeches that were given on the occasion were far from uncritical. The introductory speech by Takakuwa set the tone for the gathering and defined the task of Japanese historians. Since Ranke,

as everyone is familiar with, has recently become the founding father of History ... our goal here at this festival is to remember the great accomplishments of this man, Ranke, who cultivated the wasteland of History, applied scientific methods to our discipline and showed the traditional historians the way. It is also nothing else but to humbly improve and perfect the research methods laid out by him. Therefore, it is entirely possible to discuss and criticize without restraint those of his research methods that are not suitable for the present. $^{60}$

The language here is illuminating. For Takakuwa to say that Ranke "has recently become" a founding father clearly demonstrates that he spoke as an observer of global historiographical trends and of the growing stock value of the Rankean persona. Tsuboi and Mitsukuri, with their extensive experience as students at German universities, had no trouble situating themselves in German debates about Rankean scholarship on the virtuousness of impartiality or the primacy of foreign policy. ${ }^{61}$ What is in evidence here is a mature historiographical tradition that participated in a global conversation on the state of the discipline and did not shy away from

\footnotetext{
${ }^{56}$ According to the commemorative pamphlet. Komakichi Takakuwa, ed., Ranke sai kinen kōwa, Part 2 (Tokyo, 1904), $1 \mathrm{f}$.

${ }^{57}$ Ibid., 2.

${ }^{58}$ Juhnke, Leopold Ranke, 219.

${ }^{59}$ Takakuwa, Ranke sai kinen kōwa, Part 2, 5.

${ }^{60}$ Ibid., 2.

${ }^{61}$ On these debates see e.g. Wilfried Nippel, Johann Gustav Droysen: Ein Leben zwischen Wissenschaft und Politik (Munich, 2008), 140; Henz, Leopold von Ranke, 1: 427-62; Ulrich Muhlak, "Leopold Ranke und Karl Lamprecht," in Jonas Flöter and Gerald Diesener, eds., Karl Lamprecht (1856-1915): Durchbruch in der Geschichtswissenschaft (Leipzig, 2015), 123-46.
} 
critically appraising its great icon. In discussing Ranke's persona, the speakers at the festival simultaneously, or even primarily, negotiated the virtues that were to have relevance for their own academic community.

In the longer speech that followed, Takakuwa then introduced Ranke's biography. He also evaluated his achievements, rehearsing many familiar aspects of Ranke's life and impact: his publications, his role in the education of the next generation, the scientific accuracy of his method of criticism and, perhaps unavoidably, even a quote of "wie es eigentlich gewesen." On the other hand, there were also tendencies in Ranke that Takakuwa found "hard to agree with": his theories often "reeked of religion," and he focused too much on modern history and politics to the detriment of economic and social factors. ${ }^{62}$

The following speakers were even blunter in their criticism. Abe Hidesuke (1876-1925), who had just graduated from the department and was to become an economic historian at Keiō University soon after, declared, "There must be many who approach the reader still more vigorously. There must be many who have a deeper knowledge of politics, religion and philosophy. And there are certainly scholars endowed with more freshness and originality of ideas." ${ }^{163}$ Tsuboi, too, was outspoken about the aspects of Ranke's dispositions that he saw as unfit for his own selffashioning: "As a nationalist, I do not worship the great-man theory. As someone who believes in facts, I do not rejoice in mysticism. As an economist, I am not convinced by inspiration theory. As these are points where Ranke's and my convictions diverge, I state them here at the outset." ${ }^{\text {"64 }}$ Finally Mitsukuri: "I am truly an admirer of Ranke. (Applause). But-I am certainly not a blind follower. (Big applause)." ${ }^{65}$

All these points of criticism aside, what the participants agreed on as Ranke's greatest virtue was once more his global outlook. Again Abe:

In his view it was the lifeblood of history to always seek out universal significance in the particular ... In his "History of the Popes" he is not satisfied with just relating the character and conduct of the successive popes. He also seeks out the fate of world history below the papal tiara. The state of Christianity in China and Japan, too, is discussed in his work. Regrettably, his time and circumstances did not allow him to conduct more detailed research on this region. This is what he has bequeathed to the historians of the Far East, and I believe it is our duty to research it further. ${ }^{66}$

Mitsukuri, too, closed his speech with an acclamation of "Ranke's sharp mind-in particular his 'weltlich' (global) perspective."67 This association with a global

\footnotetext{
${ }^{62}$ Komakichi Takakuwa, "Ranke shi no jiseki ni tsukite," in Komakichi Takakuwa, ed., Ranke sai kinen kōwa (Tokyo, 1904), 1-9, at 8.

${ }^{63}$ Hidesuke Abe, "Ranke shi ni tsukite," in Komakichi Takakuwa, ed., Ranke sai kinen kōwa (Tokyo, 1904), 10-14, at 10.

${ }^{64}$ Kumezō Tsuboi, "Ranke shi no kenkyūhō yori mitaru ishin mae no gaikō ni tsukite," in Takakuwa, Ranke sai kinen kōwa, 15-19, at 15.

${ }^{65}$ Genpachi Mitsukuri, "Ranke shi ni taisuru hihyō ni tsukite," in Takakuwa, Ranke sai kinen kōwa, 2026 , at $20 \mathrm{f}$.

${ }^{66}$ Abe, "Ranke shi ni tsukite," 11.

${ }^{67}$ Mitsukuri, "Ranke shi ni taisuru hihyō," 26.
} 
historical perspective became a fixed element in Ranke's Japanese persona. Fifteen years later, his lectures for the Bavarian king Maximilian II, in German known as "Über die Epochen der neueren Geschichte" ("On the Periods of Recent History"), tellingly became "Lectures on the Theory of World History" in Murakawa Kengo's Japanese translation. ${ }^{68}$

Ironically, Ranke himself had not been convinced that Asian civilizations had much to contribute to recent world history, opining in said lectures that "the most ancient epoch of Asian culture was the most efflorescent ... With the invasion of the barbarians-the Mongols-culture came to an end." ${ }^{69}$ Still, Japanese historians chose to overlook his Eurocentrism, like Mitsukuri, who blamed it on his later interpreters; or they sequestered aspects of his personality as historically and geographically contingent, while choosing others as meaningful virtues for their own circumstances. $^{70}$

\section{Ranke's visual persona}

When we speak, as Georg Iggers did, of the circulation of Ranke's “image," it makes sense also to reflect on visual incarnations of Ranke's persona. It was mentioned earlier that the initial motivation for Murakawa Kengo to request a eulogy from Ludwig Riess was a photograph of Ranke that he planned to publish in the Historical Journal (Fig. 1). The portrait in question is dated 1885 and was probably taken around Ranke's ninetieth birthday. Ranke's gaunt face framed by a long beard, his dressing gown and sunken posture in an armchair, create the impression either of a senescent sage and grand master or of a scholar long past his prime. The same portrait resurfaces five years later as the frontispiece of the commemorative pamphlet for the Ranke festival. An illustrated supplement for a "Textbook on Western History" in the same period featured a second, similar portrait. ${ }^{71}$ Here, too, we see Ranke as an old man, with the same dressing gown, but in a more upright posture, his hair more carefully groomed-the xylography of a photograph taken around his eightieth birthday. This portrait had also appeared in Mitsukuri Genpachi's textbook Survey of Western History of 1899, with a caption introducing him as a "great authority among historians."

\footnotetext{
${ }^{68}$ Ranke, Sekaishiron shinköroku. On the title of the original text see Günter Johannes Henz, "Rankes fälschlich so benannte Vorträge Über die Epochen der Neueren Geschichte: Eine Untersuchung zu Schein und Sein der Überlieferung," Deutsche Vierteljahresschrift für Literaturwissenschaft und Geistesgeschichte 83/3 (2009), 408-51. Note that this translation and the other pre-World War II works on Ranke mentioned here are not recorded in the extensive bibliography compiled by Günter Johannes Henz, which only lists post-World War II works. Henz, Leopold von Ranke, 2: 605. Three of these are retranslations of the "Epochen," testifying to the enduring influence of the aspects of Ranke's scholarship highlighted during the Rankean moment.

${ }^{69}$ Leopold von Ranke, Über die Epochen der neueren Geschichte: Vorträge dem Könige Maximilian II. von Bayern gehalten (Darmstadt, 1959), 6.

${ }^{70} \mathrm{Cf}$. Mitsukuri, "Seiyō rekishi kyōju hō," 12.

${ }^{71}$ Senjirō Honda, Shinsen seiyōshi kyōkasho sanshō zuga (Tokyo, 1903), 100.

${ }^{72}$ Genpachi Mitsukuri and Yonezō Minegishi, Seiyōshi kō (Tokyo, 1899), frontispiece. A later edition still has the portrait, but now in the section on contemporary history. The flip side gives a short biography that attributes the small number of photographs ironically to Ranke's "extremely limited vanity." Genpachi Mitsukuri and Yonezō Minegishi, Shinpen seiyōshi kō (Tokyo, 1907), plate after 264.
} 
The popularity of these two old-age portraits raises an intriguing question: why these? Why not a reproduction of the well-known state-sanctioned oil painting created by Julius Friedrich Anton Schrader in 1868? Availability might have been an issue, but it is hard to imagine that a reprint of his official portrait or one of its copies should have been harder to come by than these old-age photographs. In fact, the portrait displayed at the Ranke festival is described in the pamphlet as an "oil painting," not a photograph, which suggests that the audience looked at a version of the Schrader painting. ${ }^{73}$ We also encounter a version of the Schrader painting in later translations of Ranke's works, in both the "Lectures on World History" and the "Modern History of Europe."74

A possible reason for the popularity of the octo- and nonagenarian portraits is given by Falko Schnicke. His close analysis of portraits of Ranke, Johann Gustav Droysen and Theodor Mommsen reveals how they "produced and conveyed statements on the legitimate subject of historiographical research"; in other words, how

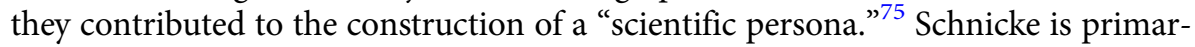
ily concerned with the encoding of the emerging discipline as male, an observation that is doubtlessly as applicable in Japan as it is in Germany. ${ }^{76}$ What is more pertinent here, however, is Schnicke's point that the paintings styled Ranke (and even more so Mommsen and Droysen) as modern, bourgeois, professional Prussian academics. ${ }^{77}$ Yet what was intended to endow the picture with universal authority from a German perspective must have parsed as specifically German for Japanese viewers. As the Schrader painting anchored Ranke as an individual in a specific time and place, it is easy to imagine why publishers found it a good fit for the Japanese translations of his works. But the Prussian medal worn by Ranke, his mid-century academic attire and the classicist interior of the room were possibly too specific and individualizing to project scholarly virtues into it that were to have validity in Japan thirty years onwards.

A British journalist who visited von Ranke on his ninetieth birthday made a remark on the distance between the painting and the man he had encountered that points in a similar direction:

\footnotetext{
${ }^{73}$ Takakuwa, Ranke sai kinen kōwa, Part 2, 2.

${ }^{74}$ Ranke, Sekaishiron shinkōroku, frontispiece; Leopold von Ranke, Ōshū kinsei shi, trans. Hidesuke Abe (Tokyo, 1923), frontispiece. The former still contains an appendix with a reprint of the nonagenarian's portrait that had been popular during the Rankean moment (plate after 467).

${ }^{75}$ Falko Schnicke, Die männliche Disziplin: Zur Vergeschlechtlichung der deutschen Geschichtswissenschaft 1780-1900 (Göttingen, 2015), 181.

${ }^{76}$ Cf. Bosch, "Scholarly Personae," 33-54; and Bonnie G. Smith, The Gender of History: Men, Women, and Historical Practice (Cambridge, 1998). On gender roles in Meiji-period Japan see Marnie S. Anderson, A Place in Public: Women's Rights in Meiji Japan (Cambridge, 2010); Jason G. Karlin, Gender and Nation in Meiji Japan: Modernity, Loss, and the Doing of History (Honolulu, 2014); Noriyo Hayakawa, "The Formation of Modern Imperial Japan from the Perspective of Gender," in Andrea Germer, Vera Mackie and Ulrike Wöhr, eds., Gender, Nation and State in Modern Japan (Milton Park, 2014), 25-47; Doris Croissant, "Icons of Feminity: Japanese National Painting and the Paradox of Modernity," in Joshua S. Mostow, Norman Bryson and Maribeth Graybill, eds., Gender and Power in the Japanese Visual Field (Honolulu, 2003), 119-40; Naoya Maekawa, Otoko no kizuna: Meiji no gakusei kara bōizu rabu made (Tokyo, 2011), chap. 1.

${ }^{77}$ Schnicke, Die männliche Disziplin, 151-81.
} 
I could not help comparing the figure of the nonagenarian historian with a fine painting overhead representing him in the bloom of manhood, trim, shorn, and shaven - a very marked contrast, indeed, to the singular personality who seemed to have actually stepped into one's presence out of the Middle Ages ... Leopold von Ranke looks like a perfect specimen of those medieval philosophers who spent their days and nights in front of huge, outspread folios ... ${ }^{78}$

In the eyes of the journalist, Ranke is reflected less as an individual than, again, a type or scholarly persona: that of the medieval philosopher. The piece thus suggests that Ranke's appearance in the old-age photograph, with its lack of clearly definable cultural or national signifiers, transcended time and space. It seems reasonable, then, that this is also what made it readily adoptable in the context of turn-of-the-century Japan.

The photographs and paintings can also be read against the traditions of Japanese painting. ${ }^{79}$ In Germany, the curators of the National Gallery in Berlin had been toying with the idea of ordering a portrait of Ranke long before they were bequeathed the Schrader portrait by him, but ultimately decided to put this idea to rest due to Ranke's deteriorating bodily condition. They were anxious to avoid projecting an image of the great master as frail and aging. ${ }^{80}$ In Japan, in contrast, a cultural uneasiness tended to surround the idea of painting sitters at too young an age, while too close a likeness could be construed as disrespectful. Most portraits up until the late Edo period (1600-1868), when a handful of literati began to experiment with Western-style painting techniques, consequently had a rather generic quality to them and were often even painted after the person in question had passed away. ${ }^{81}$ Despite being photographs, the old-age portraits of Ranke also exhibit this generic aspect, due to the limits of the technology and the blurred or fading background.

There are also some differences from typical early modern Japanese scholarly portraits concerning the posture and attributes of the sitter. While the books in the background as markers of erudition were a familiar trope in traditional paintings, and the plain robe matched the plain attire of many Japanese scholars, both the chair and the beard were more common in the Chinese tradition. Chinese scholars, most famously Confucius, were depicted sporting a beard, and they also stood or sat in chairs more often than their Japanese counterparts. ${ }^{82}$ This tradition had become popular in the eighteenth century thanks to the works of, among others, Yi Lu (1611-c.1680), which extended a strong influence on Japanese literati art and self-fashioning. ${ }^{83}$ The old-age Ranke portrait bore striking similarities in this regard to photographic portraits of Japanese scholars like the literati painter Tomioka Tessai (1836-1924), who carried on this tradition into the late nineteenth century.

\footnotetext{
78“Leopold von Ranke," The Times, 4 Jan. 1886, 3.

${ }^{79}$ Cf. Timon Screech, Obtaining Images: Art, Production and Display in Edo Japan (London, 2012), 165204; Tamagawa daigaku kyōiku hakubutsu kan, ed., Kinsei kyōikusha no shōzō (Tamagawa, 2013).

${ }^{80}$ Schnicke, Die männliche Disziplin, 208.

${ }^{81}$ Tamagawa daigaku kyōiku hakubutsu kan, Kinsei kyōikusha no shōzō, 37.

${ }^{82}$ See e.g. the portraits in Tamagawa daigaku kyōiku hakubutsu kan, Kinsei kyōikusha no shōzō, $18 \mathrm{f}$.

${ }^{83}$ See Eri Yoshida, "Edo chūki ni okeru no Rigyo (Ri Ryūō) imeeji ni kansuru ikkōsatsu," Gakushūin daigaku jinbun kagaku ronshū 8 (1999), 42-6.
} 
Regardless of whether the Japanese historians contributing to the Rankean moment had the full range of portraits to choose from, the prominence of visual portrayals in discussions of Ranke is striking; they evidently fulfilled an important function in generating and transmitting his scholarly persona in Japan. This is perhaps most apparent at the Ranke festival. The display of the portrait fulfilled the ritual purposes of honoring a scholarly ancestor and making present a learned lineage. But most of the participants were students, and for them the portrait also instantiated and focalized the disciplinary virtues and vices that were enumerated by the speakers and thus invited their internalization as part of socialization into the discipline. Falko Schnicke rightly reminds us that this function of academic portraits carried much significance in the late nineteenth century, when options to travel in person and meet other scholars were comparatively limited. In these circumstances, portraits served a "collectivizing" purpose that helped forge and sustain an imagined community and disciplinary identity. ${ }^{84}$

There is direct evidence that the portrait could focalize scholarly virtues in this sense: Kuwabara Jitsuzō (1871-1931), who had studied at the Imperial University in Tokyo and heard lectures by Riess before being appointed professor in oriental history in Kyoto in 1909, had decorated a wall of his study with a Ranke portrait. His son later remembered in a conversation on his father's scholarship, "The quality was not good; maybe it was a lithograph. But I heard from childhood that Ranke was a great scholar. That left a deep impression on me." ${ }^{85}$ Naturally, the inferior quality of the picture did not make a big difference if it was not Ranke the individual but Ranke the persona that mattered to Kuwabara. Among Ranke's virtues, the one that seems to have carried the most weight for him was his rigorous source criticism, as he often complained that Chinese scholarship was "unscientific" because most books lacked a scholarly apparatus. ${ }^{86}$ Like the biblical writing on the wall, Ranke, solemnly observing the historical work that was being carried out by Kuwabara, thus served as a constant warning to uphold the standards of the discipline.

\section{The Ranke persona in interaction}

This brings us to the question of the wider impact of the Rankean persona on Japanese historians. After all, apart from China historian Kuwabara, we have so far mostly zoomed in on the group of Japanese historians of Europe and America for the simple reason that some of them had traveled to Germany, knew some German, and were thus the first group to encounter his name, persona and work. Among the next generation of students, there were two for whom the Rankean moment sparked a deeper interest in further engagement with Ranke: Murakawa Kengo and Abe Hidesuke. They were to become the first translators of Ranke's works, and Abe later also published a history of German historiography. ${ }^{87}$ Tsuboi and Mitsukuri, the two professors of Western history, also took seriously the Japanese Rankean standards of contemporary relevance and geographical breadth of their research topics. Mitsukuri's main research focus, for example, was

\footnotetext{
${ }^{84}$ Schnicke, Die männliche Disziplin, 207.

${ }^{85}$ Tōhō gakkai, ed., Tōhōgaku kaisō II. Sengaku o kataru (2) (Tokyo, 2000), 40.

${ }^{86}$ Ibid., 42.

${ }^{87}$ Hidesuke Abe, Kinsei doitsu shigakushi (Tokyo, n.d. [c.1918]).
} 
the French Revolution and Napoleon, but he also published on the Great War and lectured about it at the universities of the Japanese armed forces. ${ }^{88}$

Yet scholarly virtues and personae are always contested and scholars rarely "appropriate a single persona, but [navigate] between multiple models of scholarly selfhood." ${ }^{89}$ In light of this and the short duration of the Rankean moment, rather than speaking of the impact of the Rankean persona per se, it makes sense to consider it in interaction. The pamphlet of the Ranke festival made clear that Japanese historians simultaneously drew on other models of virtuous disciplinary behavior: its organizers announced that they also planned a festival for the eminent Edo-period Japanese historian Arai Hakuseki (1657-1725) and, "if time permits, for outstanding Greek and Roman historians as well." ${ }^{\prime \prime 0}$ In contrast to what Herman Paul observed for Germany, however, academic historians do not appear to have positioned themselves between "pairs of proper names turned into models of virtue." ${ }^{\text {"I1 }}$ Even while discussing Ranke's weak points, there was no single other proper name that would have suggested itself as an obvious counterpart.

Things look a bit different if we also consider historians who did not work in the rarefied environment of academic history departments. In 1909, Yamaji Aizan (1865-1917), one of the writers who had been active in the Min'yūsha group, published an article on "History and Historians in Present-Day Japan" in which he distinguished between two types of history writing. As before, Macaulay is the epitome of engaging and relevant historiography and stands for history as an art. The second type is characterized by the pursuit of "historical facts for the sake of historical facts without asking whether the result of this research will move people's hearts" and a "single-minded effort concerning how to arrive at the real historical truth." Yamaji concludes, "This is the new type of historical science, and it is said that Ranke is one of its advocates." ${ }^{92}$ In a slightly amusing turn, despite Max Lenz's praise for Ranke's Goethe-like gift for storytelling, it seems that the mere fact that Ranke had been championed by academism was enough for Yamaji to put him down as the embodiment of dullness. ${ }^{93}$

To consider another example of the interaction of virtues from various sources and how they could reinforce each other, let us take one last look at the back of the cover page of the festival pamphlet. It was adorned with a poem excavated from Leopold von Ranke's diaries. It read,

Who is the force that brings forth life in me?

\footnotetext{
${ }^{88}$ Genpachi Mitsukuri, Shigan ni eizuru sekai taisen (Tokyo, 1918).

${ }^{89}$ Paul, "Virtues and Vices," 334.

${ }^{90}$ Takakuwa, Ranke sai kinen kōwa, Part 2, 3. Some years later, another group of scholars held a celebration for Zhu Shunshui (1600-82), a Chinese scholar who emigrated to Japan and became involved in an immense historical project called Dai Nihonshi. See Shu Shunsui kinenkai, ed., Shu Shunsui (Tokyo 1912). On Zhu see also Julia Ching, "Chu Shun-shui, 1600-82: A Chinese Confucian Scholar in Tokugawa Japan," Monumenta Nipponica 30/2 (1975), 177-191.

${ }^{91}$ Herman Paul, “The Virtues of a Good Historian in Early Imperial Germany: Georg Waitz's Contested Example," Modern Intellectual History 15/3 (2018), 681-709, at 709.

${ }^{92}$ Aizan Yamaji, "Nihon gendai no shigaku oyobi shika," Taiyō 15/12 (1909), 30-40, at 31.

${ }^{93}$ In this, Yamaji reproduced a common pattern where a "philological" persona is pitted against one that "allowed for greater aesthetic involvement." Cf. Paul, "Virtues and Vices," 336.
} 
Who gives insight

and understanding?

Who preserves the soul

so it will not be missed?

Oh Lord, omnipotent and triune

you called me forth from the void

here I lie before the steps of your throne. ${ }^{94}$

It should strike us as peculiar that the pamphlet was led in by a poem that spells out Ranke's religious convictions when the speeches that followed were quite frank about their disdain for Ranke's religiosity. It was certainly not selected for its aesthetic appeal, which was limited and possibly not even fully accessible to the intended audience. Nor is it probable that this was a favorite poem of Ludwig Riess's and chosen by him, both because he was Jewish and because he had returned to Germany after the end of his tenure the year before the festival. ${ }^{95}$

What remains, then, is the sheer fact of the poem being a poem. The ability to write - especially Sinitic-poetry had been an essential scholarly virtue in Japan for centuries. In composing Sinitic poetry, scholars could demonstrate their mastery of classical Chinese, the foundation of all learning until the last decades of the nineteenth century. Poetry created and exchanged on the spot in scholarly gatherings served as a social lubricant. It was also a means to express personal feelings and political opinions. ${ }^{96}$ The exalted place of poetry carried over into the Meiji period. Many intellectuals, among them Shigeno Yasutsugu, founded new poetic societies and exchanged verses with Chinese scholar-literati at the Chinese embassy in Tokyo. ${ }^{97}$ It is no surprise, then, that the biographical sketches of Macaulay and Treitschke mentioned earlier both dwelled extensively on their poetic and stylistic talents and achievements. The article on Macaulay even featured a Japanese translation of one of his poems. ${ }^{98}$

Finally, let us fast-forward to 1938, when Inoue Tetsujirō (1856-1944), professor of philosophy at the Imperial University in Tokyo, penned a recollection piece about Shigeno, his former colleague and one of the most eminent Japanese historians of the nineteenth century. ${ }^{99}$ Inoue remembered how Shigeno was already

\footnotetext{
94“"Wer ist die Kraft, / Die Leben in mir schafft? / Wer giebt Erkenntnis / Und Verständnis? / Wer bewahrt die Seele, / Dass sie nicht fehle? / Allgewaltiger, / Einer und Dreifaltiger, / Du hast mich aus dem Nichts gerufen, / Hier liege ich vor deines Thrones Stufen." Takakuwa, Ranke sai kinen kōwa, opposite 1. Recorded as "prayer" ("Gebet aus den achtziger Jahren") in Leopold von Ranke, Zur eigenen Lebensgeschichte, ed. Alfred Dove (Leipzig, 1890), 655.

${ }^{95}$ Kanai, Oyatoi gaikokujin, 134.

${ }^{96}$ Haruo Shirane, "Performance, Visuality, and Textuality: The Case of Japanese Poetry," Oral Tradition 20/2 (2005), 217-32; Matthew Fraleigh, "Songs of the Righteous Spirit: 'Men of High Purpose' and Their Chinese Poetry in Modern Japan," Harvard Journal of Asiatic Studies 69/1 (2009), 109-71; Robert Tuck, Idly Scribbling Rhymers: Poetry, Print, and Community in Nineteenth-Century Japan (New York, 2018).

${ }^{97}$ See Richard John Lynn, "Huang Zunxian and His Association with Meiji Era Japanese Literati (Bunjin): The Formation of the Early Meiji Canon of Kanshi," Japan Review 15 (2003), 101-25.

${ }^{98}$ Yabe, "Tōmasu Makōrei," $31 \mathrm{f}$.

${ }^{99}$ On Shigeno see Jirō Numata, "Shigeno Yasutsugu and the Modern Tokyo Tradition of Historical Writing," in W. G. Beasley and E. G. Pulleyblank, eds., Historians of China and Japan (London, 1961), 264-87; Yūsaku Matsuzawa, Shigeno Yasutsugu to Kume Kunitake: "Seishi" o yumemita rekishika (Tokyo, 2012); Margaret Mehl, "Shigeno Yasutsugu: Ein Überlebender kämpft um die Vergangenheit
} 
renowned for "seven strong points" during his years as a student at the Shōhei Academy. Apart from his scholarship, these were: "second, poetry, that is, Sinitic poetry; third, prose, that is, Sinitic prose; fourth, penmanship, the professor was good at calligraphy; fifth, the game of go, he was quite strong at that; sixth: the drum; and seventh, his appearance. His appearance was dignified and truly imposing. These were called Seisai's [Shigeno's] seven perfections." ${ }^{00}$ To these seven, among which, it should be duly noted, Sinitic poetry had the pride of place right after "scholarship," Inoue added three more: his "insight," by which he meant the breadth of his scholarship that went beyond Chinese and Confucian classical texts and led him to the study and renewal of Japanese history; his public speaking skills, which were not as common at that point in Japan; and his good health. ${ }^{101}$ Yet Inoue also had one point of regret about Shigeno: "If the professor had learned Western scholarship, he would have been able to make even more excellent arguments. But since ... he did not understand a word of English, French or German etc., that surely must have been frustrating and unsatisfactory." Inoue uttered this as a philosopher commenting on Shigeno's limited knowledge of European discussions of ethics, but his argument was precisely that this knowledge would have deepened Shigeno's understanding of the historical development of human morality. This shows how virtues derived from different times, places and disciplines were in play simultaneously to evaluate one scholar's historical practice. Both Inoue's definition of "insight" as related to the breadth of research interests and his critique of Shigeno's alleged lack of familiarity with Western scholarship point in the same direction: more than thirty years after the Rankean moment, the achievements of one of the most eminent Japanese historians were still measured against a standard of geographical breadth of outlook that echoed the virtues for which Ranke had been most celebrated around 1900.

\section{A Japanese Ranke for a global discipline}

In absence of previous substantial research into the Japanese encounter with Ranke, it is quite clear that the frequent, almost obstinate, reference to the German historian in earlier European and American accounts was more than anything a Eurocentric discursive device that served to assert and establish both the connection of Japanese historical scholarship to its "modern" origin in the West and its derivative character. The concept of the scholarly persona has proven helpful in cutting through this undue focus on Western origins by shifting the conversation to Japanese concerns about epistemic virtues. In breaking down Ranke into a constellation of traits, the concept of the persona allowed us to sidestep simplistic "developmental models" and see how these traits matched concerns with scholarly

der Nation," in Marie-Luise Legeland and Barbara Manthey, eds., Von Bauern, Beamten und Banditen: Beiträge zur historischen Japanforschung. Festschrift für Detlev Taranczewski zu seinem sechzigsten Geburtstag von seinen Schülern und Kollegen (Bonn, 2007), 143-57; and Demin Tao, Shigeno Yasutsugu ni okeru gaikō kanbun to kokushi: Ōsaka daigaku Kaitokudō bunko Nishimura Tenshū kyūzō shahon sanshu (Suita, 2015).

${ }^{100}$ Tetsujirō Inoue, "Shigeno Seisai hakushi tsuikai dan," Nangoku Shisō 3 (1938), 36, reprinted in Yasutsugu Shigeno, Zōtei Shigeno hakushi shigaku ronbun shū: Hokan, ed. Toshiaki Ōkubo (Tokyo, 1989), 97-106, at 100.

${ }^{101}$ Inoue, "Shigeno Seisai hakushi," $37 \mathrm{f}$. 
conduct and priorities that had occupied Japanese historians long before they discovered Ranke. ${ }^{102}$ It was precisely this mix-and-match approach as an act of cultural translation that enabled the adoption of a Rankean persona in Japan. In their survey of the global history of historiography, Georg Iggers and Edward Wang thus rightly stress the agency of Japanese scholars: "the Japanese tradition of historical study was thus reformed and transformed via a cross-cultural exchange ... In Riess's presentation of and his Japanese audience's perception of Ranke, this German master's image experienced a metamorphosis." 103

As we have seen, Japanese historians had a rather circumscribed agenda. Considering the concrete timing of their rendezvous with Ranke from 1899 to 1903 and the aspects of his persona they highlighted the most, the reason for the Rankean moment comes into relief. He received attention at the specific juncture when historical scholarship was coalescing into a global academic profession. ${ }^{104}$ This is how most Japanese historians experienced it, starting with Shigeno Yasutsugu, who had declared his conviction that "scholarship around the world has at last switched onto the same track" already in $1890 .{ }^{105}$ A globalizing discipline needed a minimal global standard, and Ranke's image proved malleable enough to serve as a blueprint persona even in Japan. What made him attractive and relevant as a model researcher there was not his method of source criticism or his impartiality, but his global outlook. Its aspiration for global validity was one of the reasons Japanese intellectuals had sought out Western science to begin with, and Ranke gave it a face.

Acknowledgements. This article started as a paper for the Persona of the Historian conference (Leiden, January 2017). I would like to thank the organizer, Herman Paul, for his kind invitation and Edward Wang for his encouraging comments. Many thanks to Sebastian Conrad and the members of the global history platform in Berlin, as well as my fellow ARNIs Lisa Hellman and Barend Noordam for their input on early drafts. I am extremely grateful to the editors and anonymous readers for their patient and constructive feedback during the peer-review process. Thank you to Li Jingyi and Wang Fengyu for their insights as art historians on the section on Ranke's visual persona. The final stages of this work were supported by the British Academy under their Newton International Fellowship scheme.

\footnotetext{
${ }^{102}$ Paul, "Sources of the Self," 147.

${ }^{103}$ Georg G. Iggers and Edward Wang, A Global History of Historiography (Harlow, 2008), 144. See also Margaret Mehl, "The European Model and the Archive in Japan: Inspiration or Legitimation?", History of the Human Sciences 26/4 (2013), 107-27; and Takenaka, "The Domestication of Universal History." Conversely, on the impact of Japanese scholarship on German historiography see Peter Griss, "Japan und Lamprechts universalgeschichtliche Anschauung 1900-1914," Comparativ: Leipziger Beiträge zur Universalgeschichte und vergleichenden Gesellschaftsforschung 4 (1991), 94-108.

${ }^{104}$ Cf. Rolf Torstendahl, The Rise and Propagation of Historical Professionalism (New York, 2015), 16891. "Global outlook" does not imply that all regions of the world enjoyed the same attention and epistemic status. See Julia Adeney Thomas, "Why Do Only Some Places Have History? Japan, the West, and the Geography of the Past," Journal of World History 28/2 (2017), 187-218; and Tanaka, Japan's Orient. See also Geert J. Somsen, "A History of Universalism: Conceptions of the Internationality of Science from the Enlightenment to the Cold War," Minerva 46/3 (2008), 361-79.

${ }^{105}$ Shigeno, "Gakumon wa tsui ni kōshō ni kisu," 39. See also Michael Facius, "Transcultural Philology in 19th-Century Japan: The Case of Shigeno Yasutsugu (1827-1910)," Philological Encounters 3/1-2 (2018), 3-33.
}

Cite this article: Facius M (2022). A Rankean Moment in Japan: The Persona of the Historian and the Globalization of the Discipline, c.1900. Modern Intellectual History 19, 217-240. https://doi.org/10.1017/ S1479244320000335 